This item was submitted to Loughborough's Research Repository by the author.

Items in Figshare are protected by copyright, with all rights reserved, unless otherwise indicated.

\title{
UK university policy approaches towards the copyright ownership of scholarly works and the future of open access
}

PLEASE CITE THE PUBLISHED VERSION

http://dx.doi.org/10.1108/AJIM-06-2016-0092

\section{PUBLISHER}

(C) Emerald

\section{VERSION}

AM (Accepted Manuscript)

\section{PUBLISHER STATEMENT}

This work is made available according to the conditions of the Creative Commons Attribution-NonCommercialNoDerivatives 4.0 International (CC BY-NC-ND 4.0) licence. Full details of this licence are available at: https://creativecommons.org/licenses/by-nc-nd/4.0/

\section{LICENCE}

CC BY-NC-ND 4.0

\section{REPOSITORY RECORD}

Gadd, Elizabeth. 2019. "UK University Policy Approaches Towards the Copyright Ownership of Scholarly Works and the Future of Open Access". figshare. https://hdl.handle.net/2134/23166. 


\title{
UK University policy approaches towards the copyright ownership of scholarly works and the future of open access
}

\author{
Elizabeth Gadd \\ Loughborough University
}

\section{This paper has been accepted for publication in the Aslib Journal of Information Management for publication in Volume 1, 2017.}

\begin{abstract}
Purpose: Considers how the open access policy environment has developed since the RoMEO (Rights Metadata for Open Archiving) Project's call in 2003 for universities and academics to assert joint copyright ownership of scholarly works. Investigates whether UK universities are moving towards joint copyright ownership.

Design: Analyses 81 UK university copyright policies are analysed to understand what proportion make a claim over i) IP ownership of all outputs; ii) the copyright in scholarly works; iii) re-using scholarly works in specific ways; iv) approaches to moral rights. Results are cross-tabulated by policy age and mission group.

Findings: Universities have not asserted their interest in scholarly works through joint ownership, leaving research funders and publishers to set open access policy. Finds an increased proportion of universities assert a generic claim to all IP (87\%) relative to earlier studies. $74 \%$ of policies relinquished rights in scholarly works in favour of academic staff. $20 \%$ of policies share ownership of scholarly works through licensing. $28 \%$ of policies assert the right to reuse scholarly works in some way. $32 \%$ of policies seek to protect moral rights. Policies that 'share' ownership of scholarly works are more recent. The UK Scholarly Communication Licence (UK-SCL) should have an impact on this area. The reliance on individual academics to enforce a copyright policy or not to opt out of the UK$\mathrm{SCL}$ could be problematic. Concludes that open access may still be best served by joint ownership of scholarly works.
\end{abstract}

Originality: This the first large-scale analysis of UK university policy positions towards scholarly works. Discovers for the first time a move towards 'shared' ownership of scholarly works in copyright policies.

\section{Introduction}

Increasing concerns about the so-called "serials crisis" - where the cost of journal subscriptions considerably exceeded the rate of inflation and the ability of libraries to pay (Okerson and O'Donnell, 1995; White and Creaser, 2004) - led to calls for scholars to self-archive copies of their research papers to make them available on open access. This came to be known as the Green road to open access as distinguishable from the Gold road of making papers available through open access (or hybrid) journals (Harnad et al, 2004). One of the key factors inhibiting such self-archiving activities was the practice, common then and still common today, of authors assigning the copyright in research papers to publishers in exchange for getting those papers published. Indeed, Banks (2016) describes the practice of assigning copyright to publishers as the "root cause" of the scholarly communication crisis facing UK universities. The assignment of copyright led to concerns from scholars that they could not self-archive their papers for fear of infringing what was now the publisher's copyright (Swan and Brown, 2004; Creaser, 2010). These issues were considered in detail by the Joint Information Systems Committee (JISC)-funded Rights Metadata in Open Archiving (RoMEO) project in 2002-2003. The resulting series of papers examined the impact of copyright on 
self-archiving (Gadd et al, 2003a, how scholars expected to both protect and use open access research papers (Gadd et al, 2003b and 2003c), and a study of publishers' copyright transfer agreements (Gadd et al, 2003d). The principal message of the first of these studies (Gadd et al, 2003a) was a call to universities to join together with their academic employees to retain the copyright in their research papers. The necessary publication rights could then be licensed to publishers, while copyright remained with the academic authors who created it, and their employing institutions who arguably owned it (more on this below), and papers could be made open access on their terms. The paper generated much discussion, including a recommendation from Denicola (2006) that scholarly works should be asserted as 'works-for-hire' (in US copyright terms) to enable universities to retain the right to make scholarly works open access, but there was no concrete action along the lines proposed. The first part of this paper considers the literature relating to the reasons for, and the consequences of, the failure of UK universities to assert joint copyright ownership in scholarly works on the development of open access. The second part provides a content analysis of 81 UK university copyright policies with a view to considering whether, after over a decade, UK universities appear to be making any policy moves towards joint ownership.

\section{Previous studies of intellectual property (IP) policies}

In the UK, copyright ownership is usually addressed as part of a university's broader intellectual property (IP) policy. There have been a small number of IP policy analyses in the last 20 years, but none with the focus or scale of this study in the UK. In 1996, Harvey performed an analysis of nine UK university IP policies with a focus on 'tangible' forms of IP (patents, software, designs, etc.,) and concluded that they were 'ill-informed, internally and externally inconsistent (p.300)'. However, it was difficult with such a small sample to assume the findings would scale up to the wider HE community. In 2000, Weedon undertook a larger study of UK university copyright policy approaches on behalf of JISC, including a survey with 87 respondents, interviews, and an analysis of 36 IP policy documents. He found that $69 \%$ of policies made a generic claim to the IP produced by staff although $53 \%$ waived rights to scholarly works. In 2001, Hannabuss wrote a paper discussing academics' IPR ownership position with reference to a small number of policy documents. Only two UK IP policy analyses have been undertaken in the last decade. A study of eight IP policy documents was performed by Rahmatian in 2014 alongside interviews with the relevant universities. The purpose was to consider universities' claims to copyright ownership in scholarly works produced by academic staff. Indeed, in all cases a generic claim to copyright produced in the course of employment was made. However, no information was provided about the characteristics of the universities studied. A study of 81 UK IP policies was undertaken by Davies in 2015 with a particular focus on their approach towards ownership of teaching materials as evidence of commitment to academic freedom. There was no analysis relating to other scholarly works.

IP policy analyses undertaken elsewhere in the world include a seminal paper by Lape, in 1992, which studied 70 US university IP policies and found that $23 \%$ "disclaimed" ownership to scholarly works. This study was repeated in 2002 by Packard, who found that the volume disclaiming ownership had increased to $71 \%$ of universities. In 2005 , Kromrey et al (2007) ran the survey again, and found that $93 \%$ of policies disclaimed scholarly works. However he also found a corresponding trend towards the claiming of royalty-free licences from academic staff to re-use their works $(14 \%$, $23 \%$, and $50 \%$ in 1998,2002 , and 2005 , respectively). He also observed a reversal of an earlier trend away from Universities claiming joint ownership of copyright from $26 \%$ in 1998, down to $7 \%$ in 2002 
and back to $26 \%$ in 2005 . This would suggest that universities are responding to academic sensitivities concerning who owns the rights in scholarly works by disclaiming sole ownership whilst retaining either a licence to re-use the works, or asserting joint copyright ownership instead.

Monotti and Ricketson's (2003) comprehensive monograph on Universities and intellectual property: ownership and exploitation included a chapter identifying the key themes addressed by institutional IP policies in the US, Australia, and the UK. Not surprisingly, it was difficult to generalise the approaches of the various policies studied towards copyright ownership. In 2008 Marshall made a study of Tertiary Education Organisations in New Zealand and found that $58 \%$ of them claimed copyright ownership of all works. No policy specifically addressed the rights of universities to place scholarly works in institutional repositories. Other studies such as those by Fine and Castagnera (2003) in the USA and Kiskis (2012) in Canada, have focussed solely on patents.

\section{Copyright ownership and open access policy developments}

\section{University open access policies and mandates}

Instead of adopting a joint copyright ownership situation as advocated by the RoMEO project, many universities responded to the advent of Green open access by adopting an open access policy (Xia et al, 2012; Harnad, 2015; ROARMap, 2016). These open access policies ranged from those that encouraged self-archiving, to those that mandated, i.e., required it. Perhaps unsurprisingly, the latter were more effective than the former (Gargouri et al, 2012). Despite the introduction of such policies, the take-up of so-called Green self-archiving, as opposed to Gold open access journals has been slow. Bjork et al (2014) estimated "realized green open access" at about $12 \%$ of total annual scholarly output which is a fraction of the $81 \%$ Laakso (2014) estimated was actually possible after embargos of up to 12 months. This has led to a further call for all open access policies to mandate rather than encourage self-archiving (Harnad, 2011), and some have analysed what makes for a strong open access mandate (Gargouri et al, 2012; Swan, 2015). However, others suggest that mandates alone will not change authors' self-archiving practice (Xia et al, 2012).

One of the strongest forms of open access mandate is the Harvard-style mandate, wherein the University not only requires academics to self-archive their papers, but to grant the university a nonexclusive licence to exercise all rights under copyright for non-commercial purposes (Shieber, 2015). This type of mandate is becoming the dominant form of open access policy in the USA (Fruin and Sutton, 2016) and is probably the closest the university community has come to the original proposal of the ROMEO project in that universities and their scholars act together to retain some rights over at least their research papers (Gadd et al, 2003). However, commentators have noted some problems with this approach. The principal concern is that, to allay academics' fears around the loss of academic freedom, they are given the right to opt out of the mandate on a case by case basis. A recent survey by Fruin and Sutton (2016) of US universities who had either 'enacted' an open access policy or had a policy 'in process' found that "most policies ( 86 percent in the Enacted Policy Group and 67 percent in the In Process Group) include language that grants automatic waivers to a faculty author on request without justification or explanation." These waivers may result in an embargo period being placed on the paper, or if the academic or publisher demands it, the paper not being made available at all. Although Harvard have reported that this affects only $5 \%$ of its papers (Banks, 2016), Fruin and Sutton found that "seventy percent of respondents in the Enacted Policy Group 
honor publisher embargoes in spite of the fact that most have non-exclusive license policies in place that should supersede any publisher-imposed restrictions." They recognise that this may be a necessary part of the transition phase to immediate open access deposit, however, it is a concern, and has led others to label such mandates as "toothless" (Eisen, 2013).

Universities in the UK, led by Imperial College London, are now acting to create their own version of the Harvard mandate known as the UK Scholarly Communication Licence (UK-SCL) (Banks, 2016). Again, authors are given the right to opt-out on a case-by-case basis, however, lee-way has been left to allow institutions to define criteria for conditions under which waivers are not acceptable. If successful, this initiative could have a significant impact on the UK scholarly communication landscape.

\section{Who owns copyright in scholarly works?}

What is interesting about open access policies and mandates of this type is that, contrary to the proposition made by the RoMEO study, they are all based on the assumption that the author is the sole rights-holder and that institutions need to ask or mandate them to make a copy of their paper available in their institutional repository. The Copyright Designs and Patents Act (CDPA, 1988) states that 'Where a literary, dramatic, musical or artistic work, or a film, is made by an employee in the course of his employment, his employer is the first owner of any copyright in the work subject to any agreement to the contrary'. However, by custom and practice, very few academic institutions have asserted this right over scholarly works.

The reluctance of universities to assert copyright in scholarly works is mainly the historical legacy of an era where i) academics were not primarily employed to create research outputs and there would have been few consequences for them if they did not; it therefore seemed fair that the author retained the rights; ii) the copyright in those outputs was considered a fair exchange for the publication of those research outputs in quality journals because the results could not be communicated in any other way, and iii) those journals were affordable enough to the institution to purchase. Of course this is no longer the case. Firstly, research measurement exercises such as the Research Excellence Framework in the UK have led to increased metrification of research activity, resulting in many UK HEls setting formal or informal minimum standards regarding the volume or quality of research outputs (which are all, of course, copyright works) that they expect staff to produce (Jump, 2015). Many scholars such as Strauss (2011), Packard (2002) and Longdin (2004) agree that "the job description of many a professor is to 'publish or perish,' that is, to create copyrightable work" (Strauss, 2011; p.35). There is therefore a strong argument that in the current research environment, academics are required by their employers to produce research outputs as well as teaching materials, and therefore in the absence of any formal agreement to the contrary, the copyright in such works automatically belongs to the employer. Secondly, the advent of information and communication technologies make the dissemination of research results a relatively cost-free exercise open to anyone with a PC and an internet connection. That is not to say that the value-added services that publishers provide around administering peer review, copy-editing, and marketing are cost-free, but communication to the public effectively is. Finally, as previously discussed, the rising cost of journals has outstripped the budgets of many university libraries (White and Creaser, 2004). 


\section{Is copyright ownership synonymous with academic freedom?}

The problem with this historical legacy is that academics have come to assume that the copyright in their scholarly works are their own (Monotti and Ricketson, 2003; Gadd et al, 2003a; Hoorn and Van de Graaf, 2006) and have come to conflate the idea of copyright ownership with that of academic freedom itself. Packard (2002; p.287) writes, "of all the arguments against the notion of university ownership of faculty work, none is more persuasive than the notion of academic freedom." Indeed, an investigation into UK universities' commitment to academic freedom by Davies (2015) used as its benchmark the degree to which universities claimed copyright ownership in teaching materials. The American Association of University Professors (AAUP) is also a strong advocate for an academic's right to intellectual property ownership as a means of protecting academic freedom. In a recent statement about the copyright ownership of Massive Open Online Courses (MOOCs), a former president of the AAUP claimed, "If we lose the battle over intellectual property, it's over. Being a professor will no longer be a professional career or a professional identity", and faculty members will instead essentially find themselves working in "a service industry," (Schmidt, 2013).

The fervour around this issue is both strong and current. Indeed, there have been two papers in the last five years by UK scholars using case law to discredit attempts by universities to assert copyright in scholarly works (Pila, 2010, and Rahmatian, 2014). The principal weapon in their armoury is an aside by Lord Evershed during the case of Stephenson Jordan (1952) thus:

$[P]$ rima facie I should have thought that a man, engaged on terms which include that he is called upon to compose and deliver public lectures or lectures to some specified class of persons, would in the absence of clear terms in the contract of employment to the contrary be entitled to the copyright in those lectures. That seems to me to be both just and commonsense.

Although the case was not actually concerning an academic and his lectures, it has been used as evidence that an academic's lectures, and by extension all of their research outputs, are not works made 'in the course of employment'. They also argue that other cases, such as Noah v Shuba (1991), define this term so narrowly that it would not extend to academic work. The first thing to note here is the age of the case law and how the nature of academia may have changed in the interim (Longdin, 2004). The second thing to note is Evershed's reference to 'the absence of clear terms in the contract of employment to the contrary'. As previous studies have shown that university IP policies are increasingly addressing the issue of rights ownership in scholarly works, it is likely that the terms of those policies would override any legislation. However, as others have noted, where there are disputes around the ownership of copyright by UK academics it is almost certain that they will be settled out of court to avoid any reputational damage. Scholars can therefore only speculate as to how a court might decide on these matters.

\section{Economic versus moral rights}

What is interesting, however, in most of the debates about who should own the copyright in scholarly works, is that copyright is treated as a single entity. Commentators argue that it should either be owned by one party or another - or shared. In actual fact, 'copyright' as commonly understood comprises a bundle of different rights. Some have divided these into 'economic' rights the right to copy, lease and sell your work and to sue for unauthorised exploitation of such rights; and 'moral rights' or droits d'auteur - the right to be attributed as the author of the work (paternity) 
and to object to any derogatory treatment of the work (integrity). In UK copyright law, employees do not enjoy moral rights in works that are created in the course of employment (CDPA, 1988; Ch. IV). This is unfortunate, because when the evidence is examined more closely, it would appear that when scholars argue for the right to retain 'copyright' it is principally the moral rights that concern them. This is best illustrated by examining the studies of a broad range of scholars' views as to who should own copyright and why.

\section{Studies of academics preferences relating to copyright ownership}

One of the earliest studies of this type was performed by Monotti and Ricketson (2003; p.406). Their survey of staff at Monash University, Australia, found that $83.6 \%$ of academics thought that they should own the rights in research materials and $75.3 \%$ thought they should own the rights in teaching materials. When respondents were asked to specify why it was they wanted to retain copyright in teaching materials, the answers included the "need to take materials to another place of employment, the desire to control publication, acknowledgement of their creative role, and the right to personal financial rewards from commercial exploitation." Of course the first and last of these reasons would not be applicable to research papers which carry no financial reward. However, the other two issues (the desire to control publication, and acknowledgement of their creative role) can be categorised as moral rights. Interestingly, Monotti and Ricketson (2003; p.407) noted that their respondents also "show a considerable degree of willingness to share ownership of both research and teaching materials, or to consider this option (almost 90 per cent altogether), thus removing the possible conclusion that academic creators believe universities should have no rights in this material."

The second major study in this area was undertaken by the RoMEO project (Gadd et al, 2003a, 2003b). The authors surveyed 542 academic authors from 57 countries and found that $61 \%$ of academics thought they owned copyright in their research papers. However, just under a third (32\%) reported that they did not know who owned the copyright and seven per cent thought their university owned the rights. Another interesting finding was that the largest proportion of respondents (49\%) said that they only signed away copyright to publishers reluctantly. Surveyed authors were asked what activities they would be willing to allow others to perform with their research papers and under which restrictions and conditions. It found that the majority of respondents were happy for their research papers to be freely displayed $(90 \%)$, given away $(73 \%)$, copied (39\%), printed (73\%), excerpted (69\%), lent $(68 \%)$, and saved $(65 \%)$, but they wanted to set limits on aggregating $(58 \%)$, modifying $(50 \%)$, annotating $(48 \%)$ and leasing $(42 \%)$. The majority (53\%) wanted to restrict the sale of their works by others. The most frequently selected restriction was the desire for all copies of their papers to be exact replicas (67\%), and the most frequently selected condition was that of author attribution (93\%). These findings demonstrate that authors are not looking for an economic return on their scholarship, although they would be unhappy for others to benefit from them financially if they do not. However, they are looking for the right of paternity (author attribution), and the right of integrity as evidenced by their desire to limit aggregation, modification and annotation and to ensure all subsequent copies of their works are exact replicas. It is interesting to note how far these findings are from many research funders' open access policies, which demand liberal re-use licences such as Creative Commons CC-BY that requires author attribution alone. Indeed, Van Noorden (2015) has reported that between 2012 and 2015 68\% of Nature authors chose the more restrictive Creative Commons CC-BY-NC-ND Licence requiring 
author attribution, and preventing derivative works and commercial re-use. This affirms the findings of the RoMEO study.

A third survey of 1,226 academic authors by Hoorn and van de Graaf (2006) showed that $71 \%$ would "prefer" to retain copyright in their scholarly works. It is perhaps not a coincidence that when asked what their 'ideal licence agreement' would look like, an identical proportion (71\%) wanted commercial reuse by others to be "(somewhat) limited".

\section{Fears around commercialisation of scholarship}

This concern around the potential for someone other than the author to benefit financially from academic authors' works appears to be at the root of much academic concern about institutional ownership of copyright. Rahmatian's 2014 paper claims that universities see the "intellectual property rights that attach to the work of their academics" as "significant and valuable assets to the university as an institution and economic organisation. (p.709)" He concludes by suggesting that universities have only developed copyright policies that claim ownership of copyright in scholarly works (on "highly doubtful" premises) because they want to commodify those works. Davies' 2015 study, although focussed on teaching materials, is based on a similar concern that "academic outputs, especially those relating to teaching, have become subject to more entrepreneurial models of higher education, becoming potentially saleable products to be owned and exploited by universities as they see fit (p.999)." However, although there may be evidence that universities are beginning to see teaching materials in that way, there is no evidence that universities view research papers as a commercial opportunity. Indeed, even Rahmatian (2014; p.734) reports that interviews with institutional representatives showed they had no interest in benefitting financially from scholarly works. He writes: "interviewees stated that the university IP policies are not supposed to hinder academics from research and publications or to control academic freedom; they are envisaged as assistance. Interviewees stressed that the purpose of [their copyright] policy is to increase research impact, to improve the chances for academics to get research grants and to raise the general university profile." Others have noted that it is not in institution's interests to impinge on academic freedom if they want to attract the best scholars (Longdin, 2004).

The evidence suggests that the 'copyright' academics are keen on retaining is not the 'copyright' that Universities have any interest in. Universities do not want to be acknowledged as the author of their employees' works, nor do they want to stop authors from exercising control over what they write or where they publish, or over how that paper is subsequently re-used (annotated, modified, etc.). However, it should be noted that there is a conflict between the re-use restrictions required by academics and the liberal re-use requirements of the various definitions of open access. For example, the Bethesda Statement on Open Access (Suber et al, 2003) includes the making and distributing of derivative works.

The only 'copyright' that universities are interested in with regards to scholarly works is the right to copy (exact replicas) and give those papers away in the form of institutional repository papers and non-commercial re-use in teaching and research. These are all rights academic authors are happy to relinquish according to the RoMEO study. Indeed universities and academic authors share the same mission in this regard, namely, to ensure research is made as openly available as possible, and as soon as possible, in order to gain the widest readership and impact. The advantage for universities is 
that, should open access succeed, it may mean a reduction in the cost of journal subscriptions which will again benefit academic authors. Having examined the evidence and taking into consideration the reluctance of most academics to assign copyright to publishers (Gadd et al, 2003a), and the willingness of most authors to share copyright with their institution (Monotti \& RIcketson, 2003) it seems extremely unfortunate that internal wrangles about who 'owns' copyright and the conflation of owning copyright with retaining academic freedom, have prevented universities and authors from joining forces and together playing a significant role in shaping the future of scholarly communication. The lack of a united university position on this has instead led to other actors setting the direction for open access, namely, research funders and publishers themselves.

\section{Research funder open access policies}

Peter Suber's Timeline of the Open Access Movement (2016) documents the birth of research funder open access policies over time and the Registry of Open Access Repository Mandates and Policies (ROARMap, [n.d.]) provides a searchable database of those policies. Figure 1 illustrates the everincreasing volume of funder (and institutional) open access policies and mandates which apply to the research papers of universities. The ROARMap database indexed 132 funder open access mandates (as of May 2016). The range of ways in which these mandates can be classified by ROARMap gives an indication of how complex the policy environment is. In total, there are 19 different headings under which the mandates can be classified, and a total of 97 different options beneath those headings. The key themes relate to whether the deposit is mandatory, what content types should be deposited and what version, where the output should be deposited, whether a particular re-use licence should apply, and whether any of the above can be waived under certain circumstances. In copyright terms, research funders are essentially asserting their rights as 'employers', or commissioners, of the research over the copyright works that result - something UK universities have so far failed to do. 


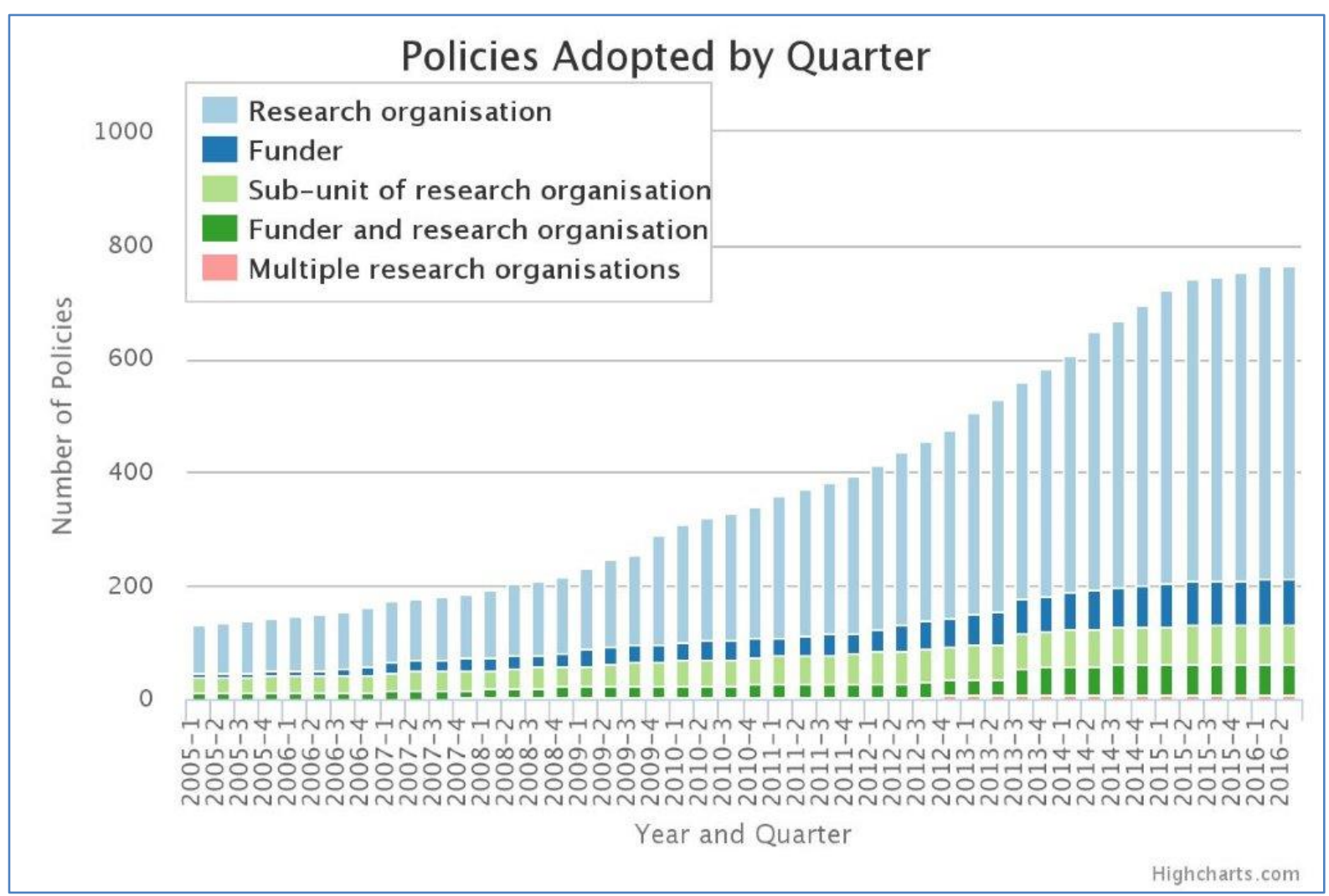

Figure 1 Development of open access policies over time

Source: ROARMap

In the UK, the policy which is set to provide the greatest momentum towards open access is the Higher Education Funding Council for England (HEFCE) Open Access policy (2015). HEFCE's policy links their open access mandate to research funding along the so-called 'Liege' model (Rentier and Thirion, 2011). Many have welcomed funders stepping into the arena as providing the necessary pressure to ensure academic authors to engage with open access (Harnad, 2015). However, the range of different funder requirements and the ensuing complexity has made for an environment which Banks (2016; p.37) has described as "sitting along a spectrum between 'wildly exciting' and 'terrifying,' and at both ends of the spectrum there are two common factors: significant institutional risk and significant potential effort and cost." The Review of the implementation of the Research Councils UK Open Access Policy found that "one of the most consistently reported issues from universities in implementing the policy was the amount of administrative effort and cost taken to set up internal policies, processes and procedures." (Burgess, 2015; p.21)

\section{Publisher open access policies}

Of course research funders are not the only players with open access policies. As a result of academic authors assigning copyright (or exclusive rights) to publishers in order to get published, publishers are the principal rights-holders in scholarly works, and as such have the greatest say as to how those works are accessed and re-used. The Rights Metadata in Open Archiving (RoMEO) database (SHERPA, 2016) of publisher open access policies serves a similar purpose to the ROARMap database of funder and institutional open access policies. It classifies publisher open access policy positions and enables authors and repository managers to assess whether a paper may be made available on open access. A recent study by Gadd and Troll Covey (2016) has demonstrated the 
increasing complexity of publishers' Green open access policies over time as documented by the RoMEO database. It shows that the number of restrictions relating to the how, where and when of self-archiving have increased by $119 \%, 190 \%$ and $1000 \%$ respectively over the twelve years since the inception of the database. Others have commented on how difficult these policies are for the authors and the repository managers who need to comply with them (Kingsley, 2013), and how it sometimes results in authors ignoring the policy provisions and self-archiving anyway (Antelmann, 2006; Troll Covey, 2009; Bjork et al, 2014). An investigation by Research Consulting (2014; p.18) into the cost of complying with the UK funders' open access mandates estimated that the time taken to 'triage' each Green open access paper (including checking publisher policies) was 20 minutes at a cost of $£ 12$. Indeed, "several institutions participating in [their] project raised the question of whether libraries' current role in rigorously policing individual deposits to ensure compliance with publisher policies is sustainable as volumes increase".

The Gadd and Troll Covey study (2016) also demonstrated how the introduction of paid (Gold) open access options over time increased at a similar rate to the volume of self-archiving restrictions. This is not surprising considering publishers are unlikely to give something away for free (immediate Green open access) that they are also selling (immediate Gold open access). However, the cost of Gold or hybrid journal Author Processing Charges (APCs) (Pinfield et al, 2015) and publishers' propensity to 'double-dip' (charging universities to publish papers and then selling them back to universities through journal subscriptions) has caused much anger in the academic community (Pinfield, 2013). Others have commented not only on the cost of the APCs, but the administrative effort involved in managing the process (Harris, 2013).

Thus, over a decade after the RoMEO Study's call for UK universities to join forces with their academic authors to take back control over their scholarly works, not only have no significant moves been made in this direction, but the scholarly environment is considerably more complex and costly to UK universities as a result. Academic authors and their representatives have to negotiate an increasingly challenging policy environment defined by research funders and publishers when, arguably, the keys to change - the ownership of copyright in scholarly works - lie firmly in their hands. The research question considered by this paper is, are UK universities any closer to making this change? It aims to answer this question through an examination of UK university copyright policies.

Although most UK universities now have open access and research data management policies, there is no real evidence that they are addressing rights ownership in any significant way. The ROARMap database ([n.d.]) shows that only eight of the 89 UK research institutions' open access policies listed (9\%) make any explicit reference to the ownership of rights, and these all assert protection for the "key rights of authors". Similarly, a recent analysis of UK university research data management policies by Horton (2014) showed that only $27 \%$ of institutional research data management policies included a statement on ownership of intellectual property (although no details were provided as to what those statements included). It can therefore be reasonably assumed that a university's IP policy is still the key place for rights ownership matters to be addressed.

\section{Methods adopted}


The vast majority of UK universities are members of Universities UK (UUK) (2015) - a group that aims to be the 'definitive voice for universities in the UK'. This group of 130 were selected as the population for this study. Others have noted the problems associated with generating a suitable sample for IP policy analyses due to the wide variety of institutions that make up the population, and the range of policy approaches (Harvey, 1996). It was therefore decided to locate as many IP policies as possible for this study. Web searches were undertaken on the Google search engine between February and April 2015 to locate the IP policies for these universities, using the institution's name and either "IP policy", "intellectual property" or "copyright policy". Where an IP policy formed a clearly identifiable part of a set of University Regulations, Research Code of Practice or Staff/Student Handbook, these were also used for analysis. However, where there was not enough information to a form a picture of the university's copyright ownership position, such documents were discounted for the purposes of this study. Where a document clearly referenced another openly available document that explicitly formed part of the university's overall approach to copyright ownership, this was analysed. A message was sent to the key UK universities' email discussion list for copyright matters, Lis-Copyseek (2015), to solicit the help of members in locating copies of closed or unlocatable copyright policies. In retrospect, it is recognised that Freedom of Information Requests could have been made to universities with closed policies in order to get a wider sample.

Policy documents were discovered for 97 of the 130 UUK members (74\%). Sixteen of these referred only to the IP ownership of students and another two were too brief to analyse. A further two 'closed' policies were obtained directly from the HEI via the Lis-Copyseek request, making the total number of staff policies analysed, $81(62 \%)$. For the population size, this sample provides a margin of error of \pm 7 at a $95 \%$ confidence level. It would not, therefore, be sensible to draw any inferential statistics from the data but the findings can be viewed as indicative.

Once the policies were identified, copies were saved to create a static reference point. As the IP policies were structured so differently and used a wide range of terminology and phraseology, it was necessary to manually read, analyse and code them. This was achievable due to the small number of key concepts investigated. However, importing the text into a qualitative analysis software package such as Nvivo or Atlas.ti would be an interesting exercise and would no doubt result in a richer analysis of the policy texts and generate new insights. The codes used to define the areas of interest to this study are given in Table 1.

\begin{tabular}{|l|l|}
\hline Area of investigation & Codes \\
\hline $\begin{array}{l}\text { Do IP policies made a general claim to IP } \\
\text { ownership of all outputs produced by academic } \\
\text { staff? }\end{array}$ & Yes; No \\
\hline $\begin{array}{l}\text { What approach do they take towards rights } \\
\text { ownership of scholarly works? }\end{array}$ & $\begin{array}{l}\text { HEI owns; HEl owns but licences/waives/assigns; } \\
\text { Staff owns; Staff owns but } \\
\text { licences/waives/assigns; Other; Free text }\end{array}$ \\
\hline $\begin{array}{l}\text { Do IP policies claim the right to re-use scholarly } \\
\text { works in some way? }\end{array}$ & $\begin{array}{l}\text { Yes or No; If Yes, for Research; Teaching; } \\
\text { Administration; Marketing; Institutional } \\
\text { Repository; General 'use'; Commercial; } \\
\text { Modification; Other }\end{array}$ \\
\hline
\end{tabular}

Table 1: Codes used to represent the areas of interest to this study 
The results were cross-tabulated with the date of the IP policy in order to identify any trends, and also with the mission group of the university to identify any significant differences in the approach of different types of university.

\section{Findings}

\section{Mission group of universities studied}

Many universities are part of a wider group of institutions that share the same educational focus, called "mission groups". Of the 81 UK HEl policies analysed, 48 were members of mission groups and were coded accordingly to allow for cross-tabluations (see Table 2):

\begin{tabular}{|l|l|l|l|l|}
\hline Mission Group & $\begin{array}{l}\text { Classification } \\
\text { for the study }\end{array}$ & Description & $\begin{array}{l}\text { Total } \\
\text { membership }\end{array}$ & $\begin{array}{l}\text { Number included } \\
\text { in sample (\% of } \\
\text { total membership) }\end{array}$ \\
\hline Guild HE & $\begin{array}{l}\text { 'New' } \\
\text { universities }\end{array}$ & Former HE colleges & 28 & 4 (14\%) \\
\hline Million + & $\begin{array}{l}\text { 'New' } \\
\text { universities }\end{array}$ & New universities & 14 & $12(85 \%)$ \\
\hline Russell Group & Russell Group & $\begin{array}{l}\text { Large, research- } \\
\text { intensive } \\
\text { universities, usually } \\
\text { ancient or 'red- } \\
\text { brick' }\end{array}$ & 24 & $18(75 \%)$ \\
\hline University Alliance & $\begin{array}{l}\text { 'New' } \\
\text { universities }\end{array}$ & $\begin{array}{l}\text { Business-facing } \\
\text { modern } \\
\text { universities for the } \\
\text { cities and regions }\end{array}$ & 18 & $14(77 \%)$ \\
\hline Not aligned & Unclassified & $\begin{array}{l}\text { Ex-1994 Group } \\
\text { institutions and } \\
\text { others }\end{array}$ & NA & 33 \\
\hline
\end{tabular}

Table 2: Membership of Mission Groups

As the numbers in each mission group were fairly low, to aid the descriptive statistics universities in the GuildHE, Million +, and University Alliance groups were grouped together as they all serve the newer, more business-facing universities. Universities not forming a part of a mission group were denoted as 'unclassified'.

\section{Date of IP policies}

The located policy documents were either in PDF, Word or HTML format. In 13 cases, no date was recorded on the policy - this was principally the case for web-based documents. In 68 other cases, a date was given. The spread of policy dates is given in Figure 2 . 


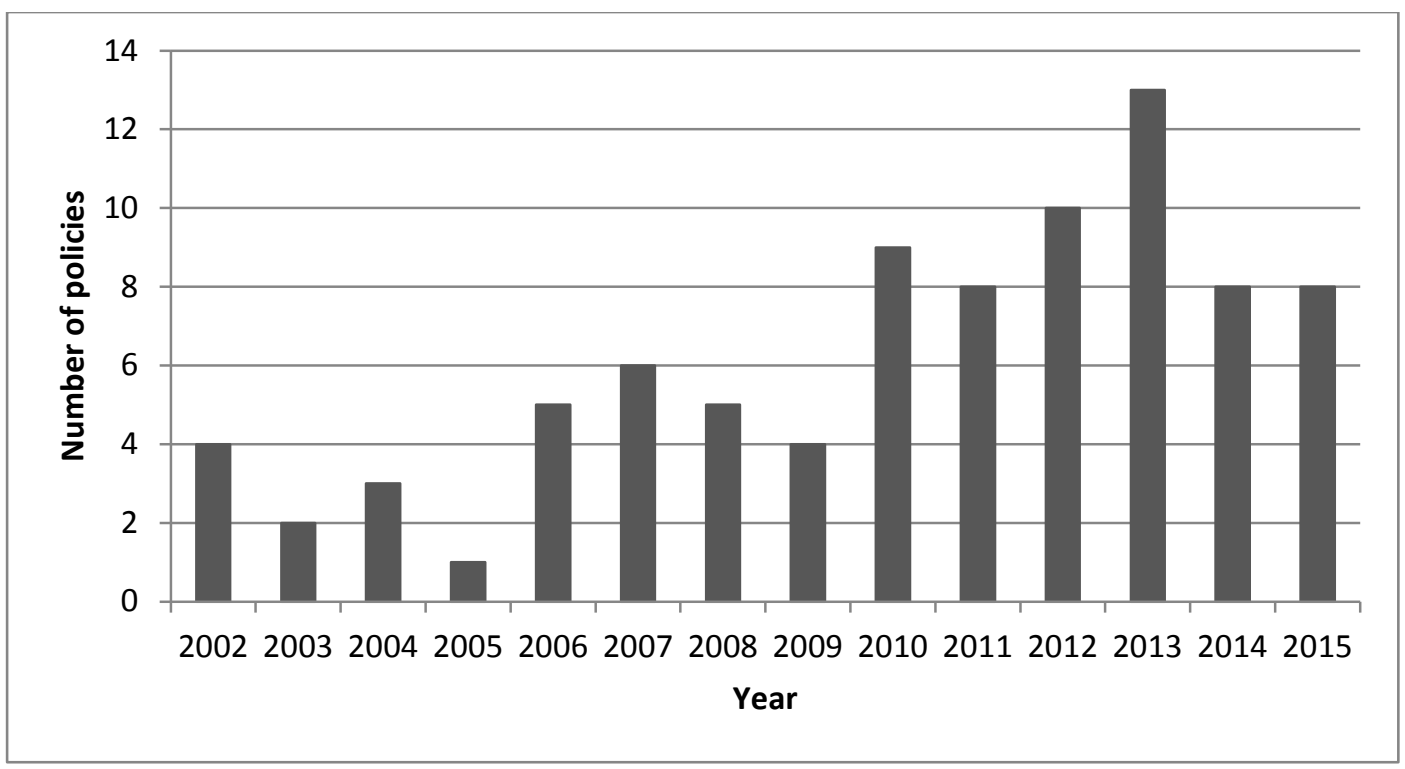

Figure 2: Date of IP policies

Although the largest group of policies (35 or 43\%) were less than five years old, 33 (40\%) were over five years old, with seven of these (8\%) being over ten years old. The accuracy of this data will, of course, be affected by the presence of IP policy statements in Staff Handbooks and Regulations. These documents tend to be re-issued each year with the current year's date even if the policies within have not been updated. This was not thought to be a considerable problem, however, because the re-issuing at least re-validated the policy as being current for the year. The mean date of an IP policy was calculated by adding together the given policy dates (years) and dividing by the number of dated policies. The mean policy date belonging to the new universities was 2009, whereas the mean date of a Russell Group IP policy was 2012.

\section{General claim to IP ownership}

The analysis found that $70 / 81$ or $86 \%$ of all policies studied made a general claim to own the IP of employees either explicitly or implicitly through s.11(2) of the UK CDPA 1988. There was no significant variation between the mission groups with over $80 \%$ of each group's IP policies making a general claim. This was an interesting contrast to the findings of the JISC study fifteen years ago (Weedon 2000), where a smaller proportion (69\%) made a general claim to own the IP produced by staff. As the JISC sample size was smaller, it is not possible to say whether the increase is due to a trend towards staking greater claim to rights ownership or not. Equally, it should not be assumed that the eleven universities not making a general claim to IP ownership did not then fail to assert any rights elsewhere in their policy.

\section{Copyright ownership of scholarly works}

Copyright policies were studied for references to 'scholarly works' (usually defined as journal articles, conference papers, or monographs). Two of the initial 81 policies were not included in this analysis due to unclear positions on ownership of scholarly works. 


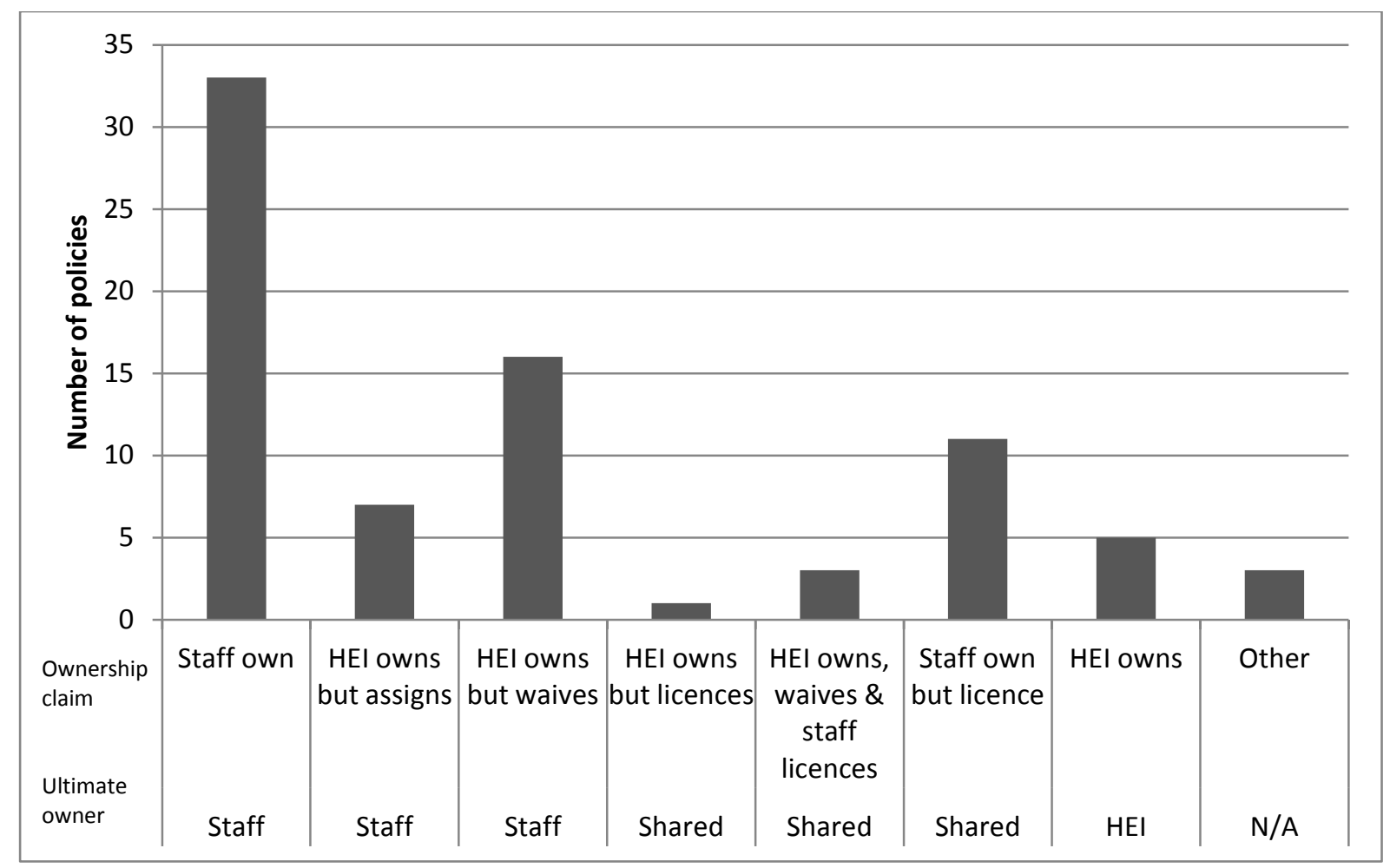

Figure 3: Copyright ownership claims over scholarly works with ultimate copyright owner indicated

Figure 3 shows the wide range of policy document positions relating to the ownership of scholarly works on a continuum from staff owning the rights through to universities (HEIs) owning the rights. Each position was categorised according to whether staff or the university (HEI) ultimately became the rights-holder as a result of the waiving, assigning and licensing of rights. For example, if a university claimed to own the rights but subsequently waived them, it was designated that staff ultimately had the right to do what they wished with their work. Where work was said to be owned by either party, but appropriate rights were 'licensed' to the other, this was classed as a sharing of rights.

It is perhaps not surprising that most policies (33) state categorically that staff own copyright in scholarly works, and the second most common approach is for universities to claim ownership, but ultimately 'waive' (16) - or waive in expectation of a licence from staff (3) - 'assign' (7) or 'license' (1) this right. In a small number of cases (5) the university claims outright copyright ownership of scholarly works. In some cases, this may be due to poorly-worded policies that stake a general claim in all IP and then fail to make any further provision for scholarly works. However, in some cases it is a deliberate policy approach evidenced by statements such as:

The University encourages its staff to assert the University's rights over material submitted for publication. Where a publisher will not grant copyright to the University, staff are encouraged to negotiate to retain the right, or be granted a licence by the publisher for themselves and the University to use the academic publication for teaching, research and open access purposes free of charge.'

This statement is a good example of the 'tortuous' wording of university copyright policies highlighted by Rahmatian (2014; p.730), indicating a "certain uneasiness of university administrations as to their true entitlement". If the university believes it owns the rights in scholarly 
works, why would a publisher need to 'grant copyright to the university'? Surely the publisher would need to negotiate a licence from the institution, and not be the body granting the licence? Similarly, if the publisher did grant a licence, should this not be with the university as the ultimate rights-holder, and not with the member of staff who is clearly just acting as the university's agent?

It is also worth considering the variety of terminology in use. What difference does it make whether a rights-holder licences, waives or assigns their rights? In practice, it probably makes very little difference in the case of university IP as so few cases are ever tested in court. However, in theory, a licence provides the licensee with written permission to make use of the intellectual property but ownership rests with the licensor. In the case of assignment, the rights are handed over to the assignee, making them the rightful owner. Where rights are waived, the situation is slightly more complex. Indeed some question whether it is possible to 'waive' copyright. In this case, assuming the university was the initial owner of copyright in a scholarly work, would a waiver allow anyone at all to do anything they wish with those materials? It is hard to imagine that this would be the intention of the university. Rahmatian (2015; p.4) discusses this issue in some detail and concludes that "the legal assessment of a 'non-assertion of copyright' clause...is a complicated matter for the lawyer".

\section{Copyright ownership of scholarly works - by mission group and policy date}

Figure 4 more clearly illustrates the ultimate ownership position of scholarly works according to the IP policies, broken down by mission group and mean policy date. The three policies in the 'Other' category in Figure 3 were not included in this analysis as they did not have a clear policy position.

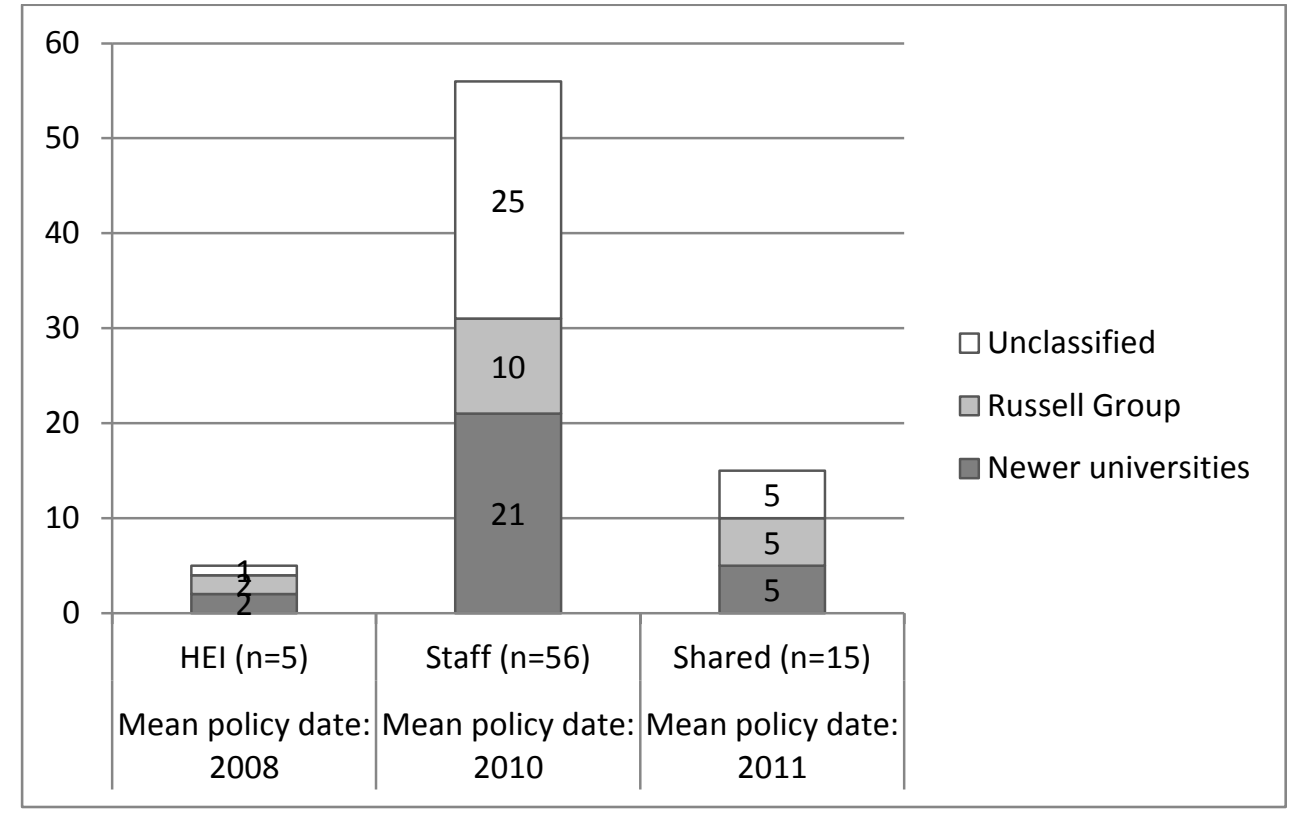

Figure 4: Ultimate copyright ownership of scholarly works by mean policy date

It can be seen that in $74 \%$ of university IP policies (56/76), staff became the ultimate rights-holders in scholarly works. This was the dominant position of all three mission groups. However, 15 university policies (20\%) opted ultimately for a 'shared' ownership situation. Figure 3 shows that in only one case is this the result of the university licensing staff to re-use their works, and in the remaining 14 cases, universities claimed a licence back from staff to re-use their works for generic 
teaching, research and administrative purposes. As discussed below, other universities also claimed re-use rights for specific activities but this was not a general licence as defined here.

Interestingly, 30\% (5/17) of Russell Group universities shared rights in this way, compared to $18 \%$ $(5 / 28)$ of new universities and $16 \%$ (5/31) of unclassified universities. The mean policy date of those opting for a shared approach is one year more recent than those policies relinquishing all rights to staff. The mean date of policies claiming ownership for the university is three years older than the policies sharing the rights. This suggests that the move towards shared ownership is a recent one, and may indicate a moving away from universities relinquishing all rights in scholarly works.

\section{Claims to re-use scholarly works in teaching and research}

Despite the fact that most copyright policies relinquished the rights in scholarly works to staff, policies were analysed to see whether any did expect to retain certain rights to reuse scholarly works. Clearly the 15 universities who opted for a shared ownership approach as identified in Figure 4, all fell within this category. However, a further seven universities also specified certain re-use requirements in their policies (e.g. to upload a copy to their institutional repository). In total, 22 universities (28\%) claimed the right to re-use scholarly works for some purpose.

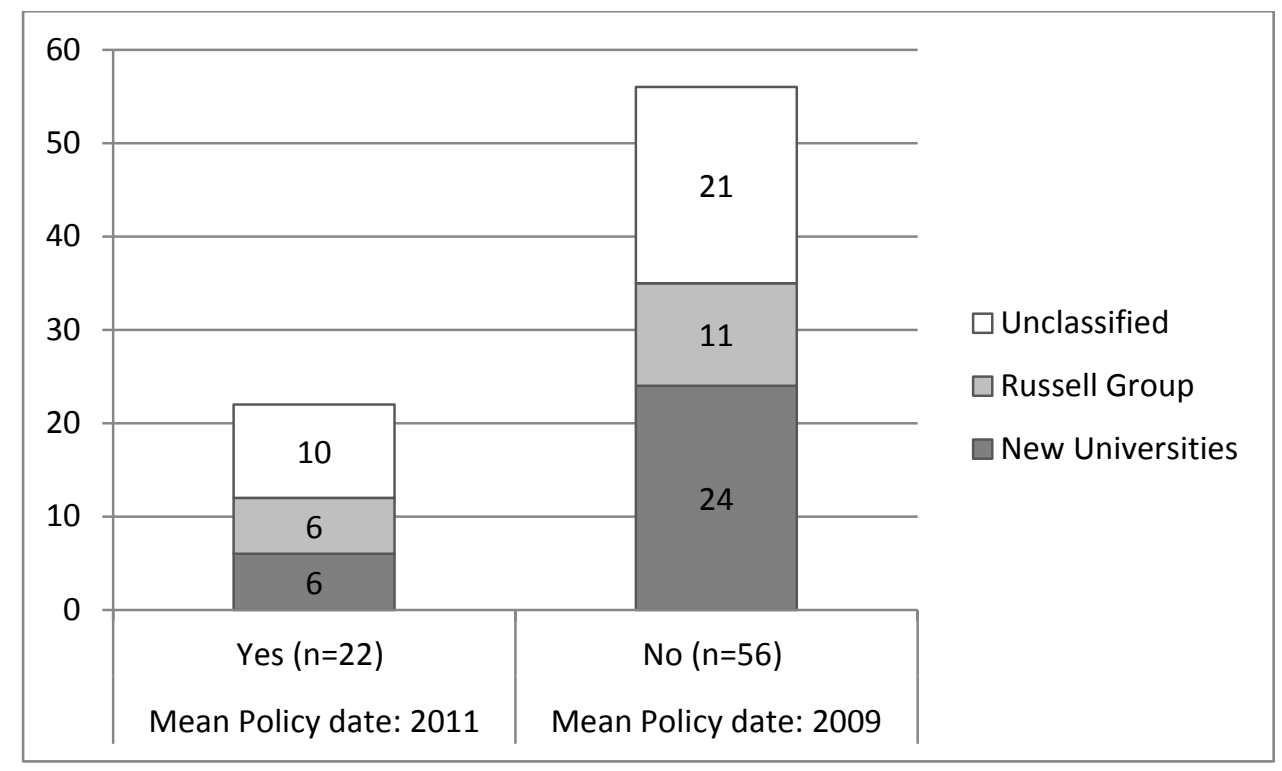

Figure 5: Do universities assert the right to re-use scholarly works in university activities? Analysis by mission group and mean policy date

Interestingly, the policies that did claim re-use rights were, on average, two years younger than those policies where they did not. Also, proportionally, these were more likely to be Russell Group institutions (6/17) than new universities (6/24), although all mission groups were represented amongst those that did claim re-use rights.

Figure 6 illustrates the re-use rights claimed by the 22 policies. Most policies claim re-use rights for more than one purpose so the numbers do not add up to 22 . 


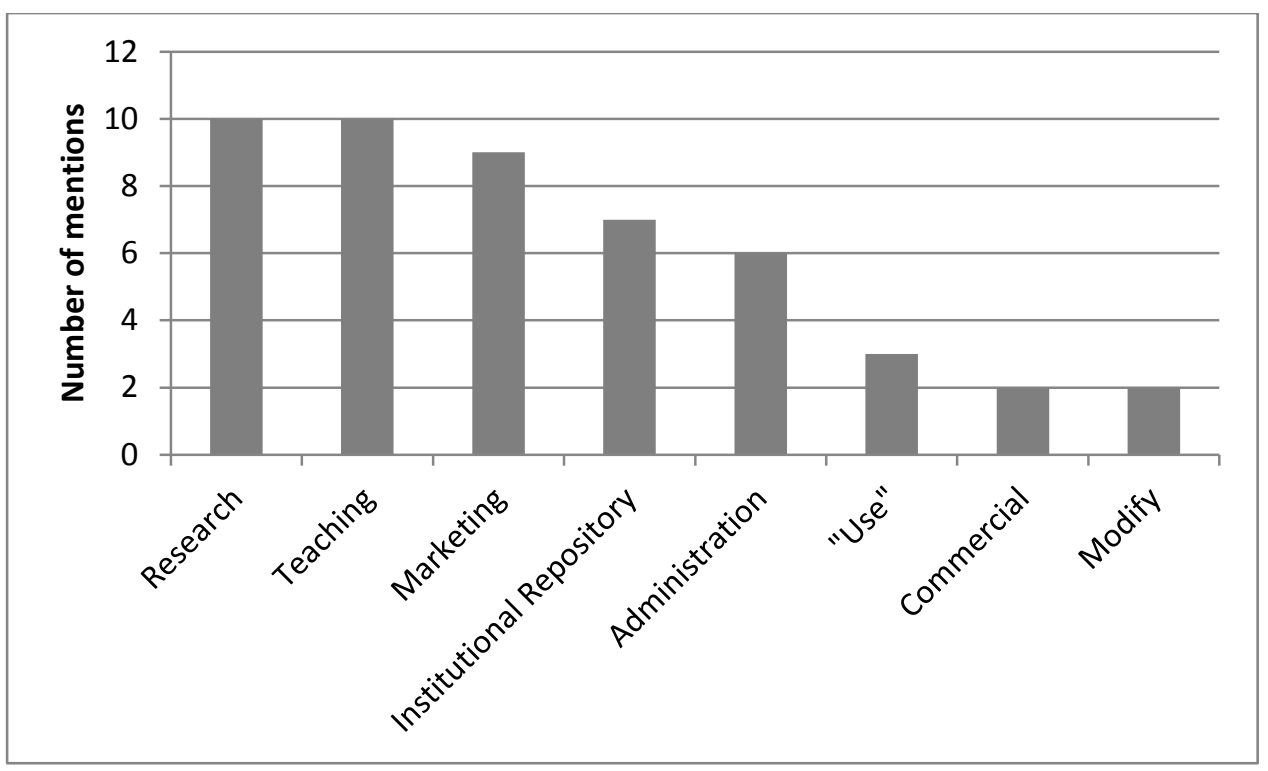

Figure 6: Re-use rights for scholarly works claimed by university IP policies

It can be seen that the most common re-use rights related to research and teaching (10/22), although not all university policies specified these together: two policies claimed re-use rights for teaching purposes only. Three policies simply claimed the right to "use" the scholarly works, which would encompass teaching and research (and presumably anything else). A specific claim to put papers on an open access institutional repository was made by nine of the policies. Interestingly, two policies claimed the right to modify the scholarly works, and two other policies claimed the right to re-use them for commercial purposes -with the proviso that revenue would be shared with the authors.

Two policies specified that the university would only assert their re-use rights if the copyright had not already been assigned to the publisher. However, ten of the 22 policies asserting re-use rights, put the onus on the academic author to either communicate this to, or negotiate this with, the publisher. For example, one unclassified university that asked staff to license them their rights in scholarly works stated, 'Any Author submitting material to be published must inform the publisher of the licence between themselves and the University'. Another, a Russell Group university, stated, 'The [university] will always insist on a royalty free, non-exclusive licence from the publisher of any Scholarly Publication to enable the [university] to use any Covered IP for promotional, administrative, educational, research and teaching purposes....It is the responsibility of Personnel to make any Publisher is aware of such agreement [sic].' Only three policies specified that academic authors should also negotiate the same re-use rights with co-authors.

\section{Approaches to moral rights}

Thirty copyright policies (37\%) made specific reference to the moral rights of authors although this was mainly in the context of teaching materials. This was a much higher proportion than Weedon's (2000) study, where only two policies mentioned moral rights. Only in four of the 30 policies was the reference seeking to underline the fact that employee-created work does not enjoy moral rights protection. The remaining 26 policies ( $32 \%$ of the total) made it explicit that, despite the law, they sought to protect the moral rights of authors with comments such as: "The University respects the 
moral rights of its employees including the right to be identified as author of the Teaching Materials, and will ensure that the author's contribution to the work is credited where appropriate." A crosstabulation by mission group showed that, proportionally, Russell Group members (7/18 or 38\%) were more likely to assert that they sought to protect the moral rights of authors, than new universities (6/30 or $20 \%)$.

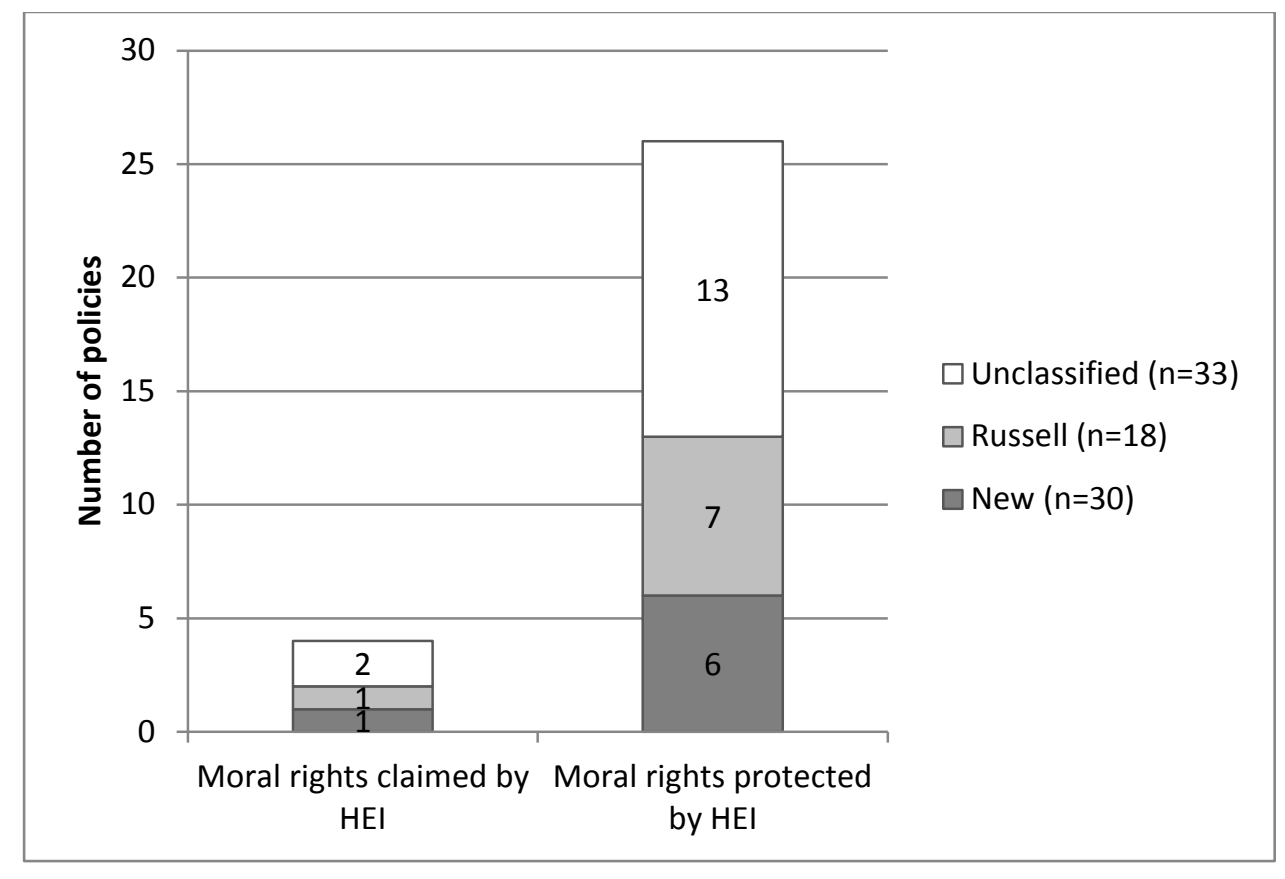

Figure 7 Copyright policy approaches towards moral rights

\section{Discussion and conclusions}

These findings show that since the publication of the RoMEO Studies in 2003, UK universities have failed to tackle head-on the controversial issue of copyright ownership of scholarly works with academics. Instead, they have chosen to introduce open access policies or mandates - which take as their starting point the academic's ownership of copyright - with varying degrees of effectiveness. Funders have taken on the role of "employer" in copyright terms, and have each introduced their own open access policy. The terms of these policies are sometimes in conflict (Banks, 2016) and have been administratively challenging (Burgess, 2015). Publishers have responded to funder open access policies in varying ways - mainly by introducing embargoes on Green open access and introducing a paid alternative, Gold open access, achieved through costly article processing charges (Pinfield et al, 2015). Not surprisingly, the current open access policy environment is not realising affordable Green open access as envisaged (Bjork, 2014; Laakso, 2014).

However, to return to the original research question as to whether UK universities are any closer to asserting themselves as a key player in the future of open access by sharing copyright ownership in scholarly works with academic authors, there are encouraging signs. This study shows an increase in the proportion of universities asserting a generic claim to all IP in line with s.11(2) of the Copyright Act $(87 \%)$ compared to that found by Weedon's study in $2003(69 \%)$. It also highlights a move towards shared ownership of scholarly works in $20 \%$ of policies with $28 \%$ of policies asserting to the right to reuse scholarly works in some way. The introduction of the UK Scholarly Communication 
Licence (UK-SCL) where universities claim a non-exclusive licence from academic staff to make their royalty-free scholarly works available on open access, is a similarly encouraging initiative. The concerns with both of these developments are the reliance on individual academics to enable them. In the case of the re-use claims asserted in university copyright policies, $45 \%$ of universities explicitly rely on academic staff to communicate these to publishers. The UK-SCL would take away the burden of communication with publishers from individual academics as institutions would take on this role. However, individual academics would still have the right to opt-out of the licence if their publisher of choice does not accept the UK-SCL terms. This will need to be monitored if the UK is to avoid the situation facing the $70 \%$ of US universities who find themselves honouring publisher embargoes as a result of $87 \%$ of their policies allowing opt-outs (Fruin and Sutton, 2016). In such cases, academics may find themselves negotiating either with the publisher for a (reduced) embargo period, or with their institution to get a waiver.

In an ironic turn, while both of these developments rely on individual academic engagement to ensure their success, neither fully address the re-use requirements academics' demand. It has been argued that when academics seek to retain copyright, it is moral rights that concern them most.

Above all, they seek to be attributed as the author of their scholarly works and to prevent what they might see to be their derogatory treatment. Whilst they seek no commercial benefit for themselves, they are concerned to prevent unauthorised commercial exploitation elsewhere. This study shows that only $32 \%$ of UK university IP policies explicitly seek to protect academics' moral rights and early indications are that the UK-SCL ultimately seeks to make scholarly works available under a liberal CCBY licence, although in the early stages a CC-BY-NC licence will be used (Banks, 2016; Reimer, 2016).

Thus, while there are encouraging signs that universities and academics are working together to establish themselves as key influencers over the future of scholarly communication, the developments are still principally based on an assumption that individual academics own the copyright in scholarly works. The fear is that because individuals acting alone have less leverage, publishers may still feel that they can set embargo periods of their choosing, and academics may still feel they have no other option than to comply. Meanwhile, universities are investing more and more time and money in administering the open access policy requirements of funders, publishers and academics, much of which could be avoided if they asserted a full joint stake in the ownership of scholarly works.

\section{Conclusions and recommendations}

A joint ownership approach has the benefit of reframing the whole scholarly communication debate. Publishers would be negotiating with large institutions or groups of institutions rather than individual academics. Academics and their employers would be on the same side, without the current tensions inherent today. Undoubtedly, cultural change on this scale would take time because copyright ownership continues to be seen as an indicator of academic freedom. However, there is good evidence that the rights universities seek to exploit (the right to make work available on open access immediately) are fully supported by academics, and the rights that academics want to protect (moral rights and the right to prevent unauthorised commercial re-use) are best supported by universities. Indeed, a conversation around the conflict between academics desire to protect their work and the open access movement's desire to liberate it, would best be held 
between academics and their university as neutral partner. Ultimately, it is in a university's best interests to fully support and protect their academics' interests. Whether the current moves towards shared ownership of rights through licensing eventually translate into a full joint ownership situation remains to be seen. However, it is recommended that universities begin to consult with their academic staff on these issues, using the UK-SCL as a starting point. The evidence presented in this paper suggests that universities and academics are beginning to recognise that a shared approach to copyright ownership is the best way to enable the effective communication and consumption of scholarship on scholars' own terms, and that a move along these lines has a greater chance of success than ever before.

It is acknowledged, however, that a change in copyright policies alone will not secure the future of open access. Firstly, it is clear from the conflicting and unenforceable terms contained in many UK university copyright policies, that there is a disconnect between policy and practice in this area. A series of interviews with UK universities to investigate the relationships between their copyright policy and its implementation would be enlightening and complement the current study. Secondly, it is important to note that the scholarly communication ecosystem involves many players and a change to one element of the ecosystem will effect change in others areas. A study of publishers' responses to the uptake of Harvard-style mandates in the US and increasingly in the UK would be very timely. It would also be interesting to note the reaction of funders over time, and whether they find it necessary to continue to prescribe forms of open access if academics and universities assert a greater sense of ownership over their research outputs. Of course, the most critical players in this ecosystem are the academic staff members themselves and it has been noted that their views are often overlooked. It has been over a decade since the last international study of researchers' views into the rights issues relating to open access. An investigation into the motivations of and rewards given to academic staff who assign copyright in exchange for publication in closed access journals, and how academics would like to protect and use open access research outputs, would be both informative and provide another forum for the discussion of these important issues.

\section{REFERENCES}

Antelmann, K. (2006), Self-archiving practice and the influence of publisher policies in the social sciences. Learned Publishing, Vol. 19, No. 2, pp.85-95.

Banks, C., (2016). Focusing upstream : supporting scholarly communication by academics. Insights, Vol. 29 No. 1, pp.37-44.

Bjork, B., Laakso, M. \& Welling, P. (2014), Anatomy of green open access. Journal of the Association for Information Science and Technology, Vol. 65, No. 2, pp.237-250.

Burgess, R. (2015), Review of the implementation of the RCUK Policy on Open Access. Available at: http://www.rcuk.ac.uk/documents/documents/openaccessreport-pdf/_Accessed 26 June 2016)

Copyright Designs and Patents Act (CDPA), 1988. Available at: http://www.legislation.gov.uk/ukpga/1988/48/section/163. (Accessed 26 June 2016) 
Creaser, C. (2010), Open Access to Research Outputs-Institutional Policies and Researchers' Views: Results From Two Complementary Surveys. New Review of Academic Librarianship, Vol. 16, No. 1, pp.4-25.

Davies, M. (2015), Academic freedom: a lawyer's perspective. Higher Education, Vol. 70, No. 6 , pp.987-1002.

Denicola, R.C. (2006), Copyright And Open Access: Reconsidering University Ownership Of Faculty Research. Nebraska Law Review, 85(2), p.351.

Eisen, M. (2013), Let's not get too excited about the new UC open access policy. It is NOT junk (blog), August. Available at: http://www.michaeleisen.org/blog/?p=1413. (Accessed 26 June 2016)

Finch, J. et al. (2012), Accessibility, Sustainability, Excellence: How to Expand Access to Research Publications, Available at: www.researchinfonet. org/wp-content/uploads/2013/02/Finalversion.pdf. (Accessed 26 June 2016)

Fine, C.R. \& Castagnera, J.O. (2003), Should there be corporate concern?: Examining American university intellectual property policies. Journal of Intellectual Capital, Vol. 4, pp.49-60.

Fruin, C. \& Sutton, S. (2016), Strategies for success: open access policies at North American Educational Institutions. College \& Research Libraries, (In press).

Gadd, E., Oppenheim, C. \& Probets, S. (2003a), RoMEO Studies 1: The impact of copyright ownership on academic author self-archiving. Journal of documentation, Vol. 59, No.3 pp.243-277. [Accessed March 4, 2013].

Gadd, E.A., Oppenheim, C. \& Probets, S. (2003b), RoMEO Studies 2: How academics want to protect their open-access research papers. Journal of information science. Vol. 29, No. 5, pp.333-356.

Gadd, E.A., Oppenheim, C. \& Probets, S. (2003c), Romeo Studies 3: How Academics Expect to Use Open Access Research Papers. Journal of Librarianship and Information Science. Vol. 35, No.3, pp 171-187.

Gadd, E.A., Oppenheim, C. \& Probets, S. (2003d), RoMEO studies 4: an analysis of journal publishers' copyright agreements. Learned publishing. Vol. 16, No. 4, pp. 293-308.

Gadd, E.A.; Brown, A. (2015), Lis-Copyseek Discussion List. Available at: https://www.jiscmail.ac.uk/lists/LIS-COPYSEEK.html. (Accessed 26 June 2016)

Gadd, E.A. \& Troll Covey, D. (2016), What does "green" open access mean? Tracking twelve years of changes to publisher self-archiving policies. Journal of Librarianship and Information Science. [In press].

Gargouri, Y. et al. (2012). Testing the Finch Hypothesis on Green OA Mandate Ineffectiveness. Available at: http://eprints.soton.ac.uk/344687/4/finch2.docx. (Accessed 14 August 2016) 
Hannabuss, S. (2001), Intellectual property rights and university employees. Library Review, 50, pp.117-122.

Harnad, S. et al. (2004), The green and the gold roads to Open Access. Nature Focus, 17 May. Available at: http://www.nature.com/nature/focus/accessdebate/21.html (Accessed 30 June 2016).

Harnad, S. (2011), Open Access to Research: Changing Researcher Behaviour Through University and Funder Mandates. JeDEM: eJournal of eDemocracy \& Open Government, Vol. 3, No.1, pp.33-41.

Harnad, S. (2015), Optimizing Open Access Policy. The Serials Librarian, Vol. 69, No. 2, pp. 133-141.

Harris, S. (2013), Implementing Open Access APCs: the role of academic libraries. A report on a roundtable commissioned by JISC. Available at:

http://www.sagepub.com/press/2013/september/SAGE rolelibrariansplayapc.sp. (Accessed 30 June 2016).

Harvey, K. (1996), Capturing intellectual property rights for the UK: a crtitique of University policies. In A. Webster \& K. Packer, eds. Innovation adn the intellectual property system. London: Kluwer Law International.

HEFCE (2015), Policy for open access in the post-2014 Research Excellence Framework. , (July 2015), Available at: http://www.hefce.ac.uk/pubs/vear/2014/201407/\#d.en.86771\nhttp://www.hefce.ac.uk/medi a/hefce/content/pubs/2014/201407/HEFCE2014 07.pdf. (Accessed 30 June 2016).

Hoorn, E. \& Van Der Graaf, M. (2006), Copyright issues in open access research journals: The authors' perspective. D-Lib Magazine, Vol. 12, No.2, pp.77-86.

Horton, L. (2014), Overview of UK Institution RDM Policies. Available at: http://www.dcc.ac.uk/resources/policy-and-legal/institutional-data-policies. (Accessed 30 June 2016).

Jump, P. (2015), The weight of numbers. Times Higher Education, 9 July.

Kingsley, D. (2013) Walking in quicksand - keeping up with copyright agreements. Australian Open Access Support Group Blog, Available at: http://perma.cc/A5ZK-J928. Accessed 14 August 2016.

Kiskis, M. (2012), Faculty intellectual property rights in Canadian universities. Baltic Journal of Law and Politics, Vol. 5, No.2, pp.81-108.

Kromrey, J., Barron, A. \& Hogarty, K. (2007), Intellectual property and online courses: Policies at major research universities. Quarterly Review of Distance Education, Vol. 8 pp.109-125.

Laakso, M. (2014), Green open access policies of scholarly journal publishers: A study of what, when, and where self-archiving is allowed. Scientometrics, Vol. 99, pp.475-494. 
Lape, L.G. (1992), Ownership of Copyrightable Works of University Professors : The Interplay between the Copyright Act and University Copyright Policies. Villanova Law Review, Vol. 37, No. 2, pp.223-271.

Longdin, L. (2004), Copyright Dowries in Academia: Contesting Authorship and Ownership of Online Teaching Materials in Common Law Jurisdictions. International Review of Intellectual Property and Competition Law, Vol. 35, No.1, ICC 22.

Marshall, S. (2008) Copyright policy issues facing tertiary institutions engaged in e-learning. Hello! Where are you in the landscape of educational technology? Proceedings ASCILITE Melbourne 2008, pp.582-592.

Monotti, A. \& Rickeston, S. (2003), Universities and intellectual property: ownership and exploitation, Oxford: Oxford University Press.

Noah v Shuba (1991) F.S.R. 14 (Ch).

Okerson, A. \& O'Donnell, J.J. (Eds. ). (1995), Scholarly journals at the crossroads: a subversive proposal for electronic publishing. Association of Research Libraries. Available at: http://catalog.hathitrust.org/Record/003013520. (Accessed 30 June 2016).

Packard, A. (2002), Copyright or Copy Wrong: An Analysis of University Claims to Faculty Work. Communication Law and Policy, Vol. 7, No.3, pp.275-316.

Pila, J., (2010), Who owns the intellectual property rights in academic work ? European Intellectual Property Review, Vol. 609, pp.1-7.

Pinfield, S. (2013), Is scholarly publishing going from crisis to crisis? Learned Publishing, Vol. 26, No.2, pp.85-88.

Pinfield, S., Salter, J. \& Bath, P.A., (2015), The "Total Cost of Publication" in a Hybrid Open-Access Environment: Institutional Approaches to Funding Journal Article-Processing Charges in Combination With Subscriptions. Journal of the Association for Information Science and Technology, Vol. 67, No. 7, pp.1751-1766.

Stevenson Jordan \& Harrison v MacDonald \& Evans (1952) 1 T.L.R. 101 (CA),

Rahmatian, A. (2014), Make the butterflies fly in formation? Management of copyright created by academics in UK universities. Vol. 34, No. 4, pp.709-735.

Rahmatian, A. (2015), University academics as employees and creators of copyright works : university academics as owners of copyright ? European Intellectual Property Review, Vol. 37, No.6, pp.355-358. 
Reimer, T. (2016), Imperial College London - journey to open scholarship. Slideshare. Available at: http://www.slideshare.net/TorstenReimer/imperial-college-london-journey-to-openscholarship. (Accessed 30 June 2016).

Rentier, B. \& Thirion, P.C. (2011) The Liège ORBi model: Mandatory policy without rights retention but linked to assessment processes. Berlin 9 Pre-conference Workshop, November 2011. Available at: http://hdl.handle.net/2268/102031 LA - en. (Accessed 14 August 2016)

Research Consulting, (2014), Counting the Costs of Open Access, Available at: http://www.ariessys.com/wp-content/uploads/Research-Consulting-Counting-the-Costs-of-OAFinal.pdf. (Accessed 30 June 2016).

ROARMAP, (2015), Registry of open access repositories mandatory archiving policies,. Available at: http://roarmap.eprints.org/. (Accessed 30 June 2016).

Schmidt, P. (2013) AAUP Sees MOOCs as Spawning New Threats to Professors' Intellectual Property. The Chronicle of Higher Education, pp.4-7. Available at: http://chronicle.com/article/AAUPSees-MOOCs-as-Spawning/139743/.(Accessed 14 August 2016)

SHERPA, (2016), SHERPA/RoMEO Publisher copyright policies and self-archiving. Available at: http://www.sherpa.ac.uk/romeo/search.php (Accessed 30 June 2016).

Shieber, S.M. (2015), A model open-access policy. Available at: https://osc.hul.harvard.edu/modelpolicy/ (Accessed 30 June 2016).

Strauss, N. (2011), Anything but Academic: How Copyright's Work-for-Hire Doctrine Affects Professors, Graduate Students, and K-12 Teachers in the Information Age. Richmond Journal of Law \& Technology, Vol. XVIII, pp.1-47.

Suber, P. et al. (2003), Bethesda statement on open access publishing. Available at: http://dash.harvard.edu/handle/1/4725199. (Accessed 30 June 2016).

Suber, P. (2016), Timeline of the open access movement. Available at: http://legacy.earlham.edu/ peters/fos/timeline.htm. (Accessed 30 June 2016).

Swan, A. (2015), Open Access policy effectiveness : A briefing paper for research institutions. , (September), Available at: http://www.pasteur4oa.eu/sites/pasteur4oa/files/resource/Policy effectiveness - institutions final.pdf. (Accessed 30 June 2016).

Swan, A. \& Brown, S. (2004), Authors and open access publishing. Cogprints, pp.219-224. Available at: http://www.trans.uma.es/numeros.html. (Accessed 30 June 2016).

The National Archives (1988), Copyright, Designs and Patents Act 1988. Section 163. Available at: http://Www.Legis/ation.Gov.Uk/Ukpga/1988/48/Section/163, (Accessed 30 June 2016). 
Troll Covey, D. (2009). Self-Archiving Journal Articles: A Case Study of Faculty Practice and Missed Opportunity. portal: Libraries and the Academy, 9 (April), pp.223-251.

Universities UK, (2015) Available at: http://www.universitiesuk.ac.uk/Pages/default.aspx. (Accessed 30 June 2016).

Van Noorden, R. (2013), Researchers opt to limit uses of open-access publications. Nature, (June), pp.5-9.

Weedon, R. (2000), Policy approaches to copyright in HEls, Stratchlyde: Centre for Educational Systems, University of Strathclyde; Joint Information Systems Committee.

White, S. \& Creaser, C. (2004), Scholarly Journal Prices: selected trends and comparisons. LISU Occasional Paper no. 34, Loughborough; LISU.

Xia, J. et al, (2012),A review of open access self-archiving mandate policies. portal: Libraries and the Academy, Vol. 12, No.1, pp.85-102. 